\title{
PERANAN STATISTIKA DALAM PENELITIAN SOSIAL KUANTITATIF
}

\author{
Rudini, M.Pd \\ Program Studi Teknik Informatika, STMIK Palangkaraya \\ Jalan G.Obos, No 114 \\ aspurani@gmail.com
}

\begin{abstract}
ABSTRAK
Statistika merupakan suatu ilmu mengumpulkan, mengolah, menyajikan, menganalisis dan menginterpretasikan data yang diperoleh menjadi informasi untuk membantu dalam pengambilan keputusan yang efektif. Statistika juga bisa dijadikan alat untuk mempermudah perhitungan data yang berbentuk angka-angka. Dalam penelitian sosial yang bersifat kuantitatif, peran statistika sangat besar. Dimulai dari sebelum penelitian, saat melakukan penelitian sampai pengolahan data penelitian. Proses statistika dimulai dengan teknik sampling, uji validitas dan reabilitas, uji hipotesis, analisis data dan penafsirannya. Penyajian data awal digunakan statistika deskriptif dengan membuktikan secara kuantitatif.
\end{abstract}

\section{Kata kunci : Statistika, Penelitian Kuantitatif}

PENDAHULUAN

Dalam dunia pendidikan, penelitian bukanlah sesuatu yang baru, sejak dahulu sampai sekarang telah dilakukan oleh para peneliti. Penelitian membuat dunia pendidikan semakin berkembang dan maju karena banyak temuan-temuan dimanfaatkan untuk menentukan kebijakan penting baik dalam hal yang berhubungan dengan pengembangan ilmu maupun menjadi pedoman dalam mengambilan suatu keputusan yang efektif. Semua lembaga atau dinas-dinas dikabupaten/kota menggunakan statistik. Statistik memegang peranan yang penting dalam penelitian terutama metode penelitian kuantitatif, statistik berperan baik dalam penyusunan model, perumusan hipotesa, dalam pengembangan alat dan instrumen pengumpulan data, dalam penyusunan desain penelitian, dalam penentuan sampel dan dalam analisa data. Dalam banyak hal, pengolahan dan analisa data tidak luput dari penerapan teknik dan metode statistik tertentu, yang mana kehadirannya dapat memberikan dasar bertolak dalam menjelaskan hubungan-hubungan yang terjadi. Statistik dapat digunakan sebagai alat untuk mengetahui apakah hubungan kausalitas antara dua atau lebih variabel benar-benar terkait secara benar dalam suatu kausalitas empiris ataukah hubungan tersebut hanya bersifat random atau kebetulan saja.

Statistik telah memberikan teknik-teknik sederhana dalam mengklasifikasikan data serta dalam menyajikan data secara lebih mudah, sehingga data tersebut dapat dimengerti secara lebih mudah. Statistik telah dapat 
menyajikan suatu ukuran yang dapat mensifatkan populasi ataupun menyatakan variasinya, dan memberikan gambaran yang lebih baik tentang kecenderungan tengah-tengah dari variabel. Statistik dapat membantu peneliti untuk menyimpulkan apakah suatu perbedaan yang diperoleh benarbenar berbeda secara signifikan. Apakah kesimpulan yang diambil cukup refresentatif untuk memberikan infrensi terhadap populasi tertentu. Teknikteknik statistik juga dapat digunakan dalam pengujian hipotesa, mengingat tujuan penelitian pada umumnya adalah untuk menguji hipotesa-hipotesa yang telah dirumuskan, maka statistik telah banyak sekali menolong peneliti dalam mengambil keputusan untuk menerima atau menolak suatu hipotesa. Statistik juga dapat meningkatkan kecermatan peneliti dalam rangka mengambil keputusan terhadap kesimpulankesimpulan yang ingin ditarik. Penarikan kesimpulan secara statistik memungkinkan peneliti melakukan kegiatan ilmiah secara lebih ekonomis dalam pembuktian kebenaran hipotesis (dugaan sementara) yang terlebih dahulu dirumuskan.

\section{TINJAUAN PUSTAKA}

\section{A. Sejarah Statistika}

Penggunaanistilah statistika ber akar dari istilah istilah dalam bahasa latin modern statisticum collegium ("dewan negara") dan bahasa Italia statista ("negarawan" atau "politikus"). Gottfried Achenwall (1749) menggunakan Statistik dalam bahasa Jerman untuk pertama kalinya sebagai nama bagi kegiatan analisis data kenegaraan, dengan mengartikannya sebagai "ilmu tentang negara (state)". Pada awal abad ke-19 telah terjadi pergeseran arti menjadi "ilmu mengenai pengumpulan dan klasifikasi data". Sir John Sinclair memperkenalkan nama (Statistics) dan pengertian ini ke dalam bahasa Inggris. Jadi, statistika secara prinsip mula-mula hanya mengurus data yang dipakai lembagalembaga administratif dan pemerintahan. Pengumpulan data terus berlanjut, khususnya melalui sensus yang dilakukan secara teratur untuk memberi informasi kependudukan yang berubah setiap saat.

Pada abad ke-19 dan awal abad ke-20 statistika mulai banyak menggunakan bidang-bidang dalam matematika, terutama peluang. Cabang statistika yang pada saat ini sangat luas digunakan untuk mendukung metode ilmiah, statistika inferensi, dikembangkan pada paruh kedua abad ke-19 dan awal abad ke-20 oleh Ronald Fisher (peletak dasar statistika inferensi), Karl Pearson(metode regresi linear), dan William Sealey Gosset (meneliti problem sampel berukuran kecil). Penggunaan statistika pada masa sekarang dapat dikatakan telah menyentuh semua bidang ilmu pengetahuan, mulai dari astronomi hingga linguistika.

Bidang-bidang ekonomi, biologi dan cabang-cabang terapannya, serta psikologi banyak dipengaruhi oleh 
statistika dalam metodologinya. Akibatnya lahirlah ilmu-ilmu gabungan seperti ekonometrika, biometrika (atau biostatistika), dan psikometrika. Meskipun ada pihak yang menganggap statistika sebagai cabang dari matematika, tetapi sebagian pihak lainnya menganggap statistika sebagai bidang yang banyak terkait dengan matematika melihat dari sejarah dan aplikasinya. Di Indonesia, kajian statistika sebagian besar masuk dalam fakultas matematika dan ilmu pengetahuan alam, baik di dalam departemen tersendiri maupun tergabung dengan matematika.

\section{B. Pengertian Statistika}

Statistika adalah ilmu yang mempelajari bagaimana merencanakan, mengumpulkan, menganalisis, menginterpretasi, dan mempresentasikan data. Singkatnya, statistika adalah ilmu yang berkenaan dengan data. Istilah 'statistika' (bahasa Inggris: statistics) berbeda dengan 'statistik' (statistic). Statistika merupakan ilmu yang berkenaan dengan data, sedang statistik adalah data, informasi, atau hasil penerapan algoritma statistika pada suatu data. Dari kumpulan data, statistika dapat digunakan untuk menyimpulkan atau mendeskripsikan data; ini dinamakan statistika deskriptif. Sebagian besar konsep dasar statistika mengasumsikan teori probabilitas. Beberapa istilah statistika antara lain: populasi, sampel, unit sampel, dan probabilitas. Statistika merupakan suatu ilmu mengumpulkan, mengolah, menyajikan, menganalisis dan menginterpretasikan data. Paradigma penelitian dengan pendekatan kuantitatif adalah pendekatan penelitian yang berpijak pada pandangan positivisme yang intinya menekankan pada hal-hal yang bersifat kongkrit, uji empiris dan faktafakta yang nyata.

Statistika banyak diterapkan dalam berbagai disiplin ilmu, baik ilmuilmu alam (misalnya astronomi dan biologi maupun ilmu-ilmu sosial (termasuk sosiologi dan psikologi), maupun di bidang bisnis, ekonomi, dan industri. Statistika juga digunakan dalam pemerintahan untuk berbagai macam tujuan; sensus penduduk merupakan salah satu prosedur yang paling dikenal. Aplikasi statistika lainnya yang sekarang popular adalah prosedur jajak pendapat atau polling (misalnya dilakukan sebelum pemilihan umum), serta hitung cepat (perhitungan cepat hasil pemilu) atau quick count. Di bidang komputasi, statistika dapat pula diterapkan dalam pengenalan pola maupun kecerdasan buatan. Paradigma ini meyakini bahwa satu-satunya pengetahuan (knowledge) yang valid adalah ilmu pengetahuan (science), yaitu pengetahuan yang berawal dan didasarkan pada pengalaman (experience) yang tertangkap lewat pancaindera untuk kemudian diolah oleh nalar (reason). Oleh karena itu dalam prakteknya, penelitian dengan pendekatan kuantitatif ini memberikan pemaknaan melalui penafsiran angkaangka statistika atau bukan melalui kebahasaan atau kulturnya. Statistika dalam penelitian pendekatan kuantitatif 
merupakan salah satu komponen utama dalam tahapan penelitian, mulai dari persiapan penelitian, teknik pengambilan data, pengolahan data sampai pada upaya membuat keputusan/kesimpulan secara ilmiah. Dengan demikian statistika dalam penelitian dengan pendekatan kuantitatif memiliki peranan yang cukup dominan dalam memperlancar pencapaian tujuan penelitian.

\section{Peranan Statistika}

Ada empat peranan dalam penelitian, antara lain:

Pertama, Peranan Statistika dalam Penentuan Sampel Penelitian. Tujuan teknik penentuan sampel adalah agar diperoleh sampel yang representative bagi populasinya dan diperoleh ukuran sampel yang memadai untuk dilakukannya penelitian. Berkaitan dengan peranan ini, statistika menyediakan teknik-teknik dan rumusrumus tertentu agar diperoleh sampel yang reperesentatif dan ukuran sampel yang memadai.

Kedua, Peranan Statistika dalam Pengembangan Alat Pengambilan data. Sebelum seseorang menggunakan suatu alat pengambil data, dia harus mempunyai kepastian bahwa alat yang digunakannya itu berkualitas. Kualitas alat pengumpulan data dapat dilihat dari sisi validitas dan reliabilitasnya. Oleh karena itu setiap alat pengumpulan data perlu diuji tingkat validitas dan relibilitasnya, dan cara terbaik untuk menguji vasliditas dan reliabilitas alat pengumpulan data adalah dengan menggunakan metode statistik.
Ketiga, Peranan Statistika dalam Menyajikan data. Data yang dikumpulkan melalui teknik pengambilan data tertentu masih bersifat data mentah, oleh karena itu agar data itu lebih komunikatif maka harus disajikan sedemikian rupa sehingga data mudah dibaca atau dipahami. Berkaitan dengan upaya untuk menampilkan data agar mudah dibaca dan dipahami, maka statistika menyediakan teknik tertentu dalam mengolah data dan menyajikan data, yaitu dengan metode statistika deskriptif.

Keempat, Peranan Statistika dalam Analisis Data atau Menguji Hipotesis. Tujuan akhir dalam kegiatan penelitian adalah adanya kesimpulan sebagai bahan untuk mengambil keputusan. Agar diperoleh hasil penelitian yang valid dan reliabel, statistika juga telah mengembangkan teknik-teknik perhitungan tertentu dan mengembangkan berbagai metode untuk menguji hipotesis yang dapat membantu para peneliti. Statistika yang membahas tentang analisis data atau menguji hipotesis ini adalah metode statistika inferensial.

Sugiono dalam bukunya "Statistika untuk Penelitain” (2013: 20) menggambarkan peranan statistik dalam penelitian sbb:

1. Alat untuk menghitung besarnya anggota sampel yang diambil dari suatu populasi. Dengan demikianjumlah sampel yang diperlukan lebih dapat dipertanggungjawabkan.

2. Alat untuk menguji validitas dan reliabilitas instrument. Sebelum 
instrument digunakan untuk penelitian, maka harus diuji validitas dan relabilitasnya terlebih dahulu.

3. Teknik-teknik untuk menyajikan data, sehingga data lebih komunikatif. Teknik-teknik penyajian data seperti ini antara lain: table, grafik, diagram lingkaran dan pictogram.

4. Alat untuk analisis data seperti menguji hipotesis penelitian yang diajukan. Dalam hal ini statistik yang digunakan antara lain: korelasi, regresi, t-test, anova dll

Statistika yang telah dikembangkan secara matematis, kemudian digunakan diberbagai bidang untuk membantu memecahkan berbagai persoalan pada masing-masing bidang. Karena alasan tertentu, seringkali kita tidak memiliki data dari seluruh populasi yang hendak diamati. Kita biasanya hanya memiliki data dari sebagian populasi yang disebut sampel. Ukuran-ukuran yang langsung diperoleh dari perhitungan terhadap data sampel disebut statistik. Sedangkan ukuranukuran yang menjelaskan ciri atau karakteristik yang diperoleh langsung dari populasi disebut parameter. Statistik adalah kata yang digunakan untuk menyatakan sekumpulan fakta, umumnya berbentuk angka-angka yang disusun dalam tabel atau diagram yang melukiskan atau menggambarkan suatu kumpulan data yang mempunyai arti. Sedangkan Statistika adalah ilmu yang mempelajari tentang statistik yaitu suatu pengetahuan yang berhubungan dengan cara- cara pengumpulan fakta, pengolahan, penganalisisan, dan penarikan kesimpulan serta pembuatan keputusan yang cukup beralasan berdasarkan fakta yang ada.

Menurut Riduwan dalam bukunya"Pengantar Statistik Sosial" statistika dapat digunakan sebagai alat:

1. Komunikasi sebagai penghubung beberapa pihak yang telah menghasilkan data statistika atau berupa analisis statistik sehingga beberapa pihak tersebut akan dapat mengambil keputusan melalui informasi tersebut.

2. Deskripsi yaitu penyajian data dan mengilustrasikan data misalnya mengukur hasil produksi, laporan hasil liputan berita, indeks harga konsumen, laporan keuangan, tingkat inflasi, jumlah penduduk, hasil pendapatan dan pengeluaran negara dan lain sebagainya.

3. Regresi yaitu meramal pengaruh data yang satu dengan data yang lainnya dan untuk mengantisipasi gejala-gejala yang akan datang.

4. Korelasi yaitu untuk mencari kuatnya atau besarnya hubungan data dalam suatu penelitian.

5. Komparasi yaitu membandingkan data dua kelompok atau lebih.

D. Jenis-jenis Statistika

Jenis Statistika berdasarkan cara pengelohan data:

a. Statistika deskriptif

Statistika deskriptif adalah statistik yang berkenan dengan bagaimana cara mendeskripsikan, menggambarkan, menjabarkan atau menguraikan data sehingga mudah dipahami. Statistika deskriptif juga mempelajari tata 
cara penyusunan dan penyajian data yang dikumpulkan dalam satu penelitian. Hanya menggambarkan karakter suatu kelompok,sampel atau data, tidak dimaksudkan untuk membuat kesimpulan yang lebih luas (generalisasi). Statistik deskriptif menggunakan metode numerik dan grafis untuk mengenali pola sejumlah data, merangkum informasi yang terdapat dalam data tersebut dan menyajikan informasi tersebut dalam bentuk yang diningkan. Ada beberapa cara yang digunakan dalam mendeskripsika, menggambarkan, menjabarkan, atau menguraikan data antara lain:

1. Menentukan ukuran dari data, seperti: nilai modus, rata-rata, dan nilai tengah (median).

2. Menentukan ukuran variabilitas data, seperti: varians (varian), tingkat penyimpangan (deviasi standar), dan jarak (range).

3. Menentukan ukuran bentuk data: skewness, kurtosiss dan plot boks.

b. Statistika Inferensi

Statistika Inferensial $\begin{array}{r}\text { adalah } \\ \text { serangkaian }\end{array}$ teknik $\begin{array}{r}\text { yang } \\ \text { digunakan untuk mengkaji, }\end{array}$
menaksir dan mengambil
kesimpulan berdasarkan data yang
diperoleh dari sampel untuk
menggambarkan karakteristik atau
ciri dari suatu populasi. Statistika
Inferensial juga menganalisis data
sampel dan hasilnya akan
digeneralisasi di tingkat populasi

tempat sampel diambil.

Berdasarkan ruang lingkup bahasanya, maka statistik inferensial mencakup:

1. Probabilitas atau teori kemungkinan

2. Distribusi teoritis

3. Sampling dan sampling distribusi

4. Pendugaan populasi atau teori populasi

5. Uji hipotesis

6. Analisi korelasi dan uji signifikansi

7. Analisis regresi untuk peramalan

8. Analisis varians

9. Analisis konvarians

Jenis Statistika berdasarkan cara pengelohan data

a. Statistika Parametrik

Statistika Parametrik adalah statistika yang mempertimbangkan jenis sebaran/distribusi data yang berdistribusi normal dan memiliki varians homogen. Pada umumnya, data yang digunakan pada statistika parametrik ini bersifat interval dan rasio.

Uji statistik yang dapat digunakan pada statistika parametrik, antara lain:

1. Uji $-\mathrm{Z}$ ( 1 atau 2 sampel)

2. $\mathrm{Uji}-\mathrm{T}$ (1 atau 2 sampel)

3. Korelasi pearson

4. One or two way ANOVA test

5. Analisis regresi

b. Statistika NonParametrik

Statistika Nonparametrik merupakan bagian statitik yang parameter populasinya atau 
datanya tidak mengikuti suatu distribusi tertentu atau memiliki distribusi yang bebas dari persyaratan dan variansnya tidak perlu homogen. Statistika nonparametrik biasanya digunakan untuk melakukan analisis pada data berjenis nominal atau ordinal.

Analisis statistika nonparametrik, antara lain:

1. Uji tanda peringkat Wilcoxon dan Uji U mannWithney (untuk 1-2 kelompok)

2. Uji Kruskal-Wallis (untuk kelompok lebih dari 2)

3. Uji korelasi Rank Spearman dan Kendall Tau

4. Uji Chi-kuadrat.

\section{Teknik Sampling}

Teknik Sampling adalah teknik pengambilan sampel dalam penelitian. Jenis-jenis teknik sampling dapat dilihat pada gambar di bawah ini :

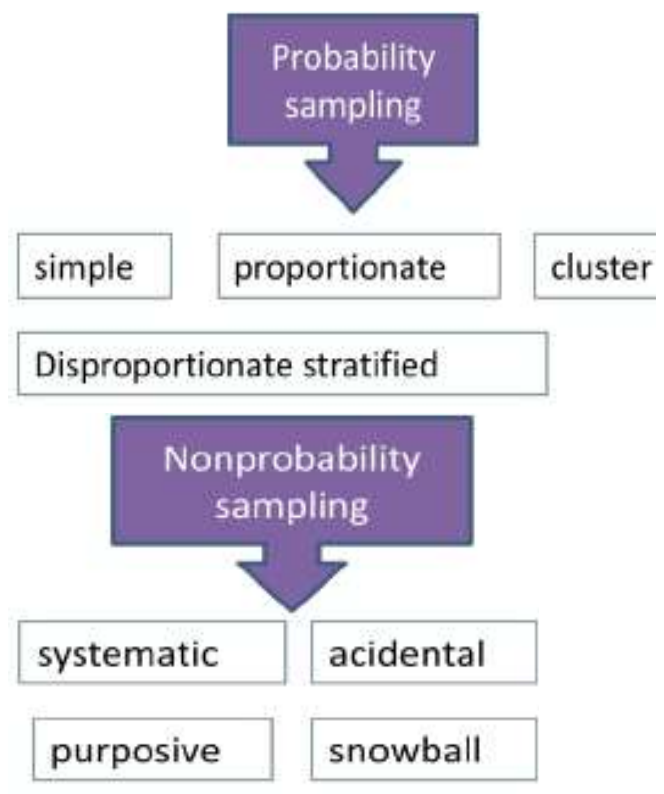

1. Probability sampling adalah teknik sampling yang memberikan peluang yang sama bagi seluruh anggota populasi untuk dipilih menjadi anggota sampel.

a. Simple random sampling merupakan teknik sampling yang dilakukan secara acak tanpa strata dimana populasi relatif homogen.

b. Proportionate random sampling merupakan teknik sampling yang dilakukan secara acak pada populasi berstrata secara proporsional.

c. Disproportionate stratified random sampling merupakan teknik sampling yang dilakukan secara acak pada populasi berstrata secara kurang proporsional.

d. Cluster random sampling merupakan teknik sampling yang dilakukan secara acak pada daerah yang luas yang terbagi-bagi menjadi daerah yang kecil-kecil.

2. Nonprobability sampling adalah teknik sampling yang tidak memberikan peluang yang sama bagi seluruh anggota populasi untuk dipilih menjadi anggota sampel.

a. Systematic sampling adalah teknik sampling dimana pemilihan sampel pertam secara acak sedangkan sampel berikutnya dipilih secara sistematis berdasarkan urutan.

b. Acidental sampling adalah 
teknik sampling berdasarkan kebetulan.

c. Purposive sampling adalah teknik sampling dengan pertimbangan tertentu.

d. Snowball sampling adalah teknik sampling secara berantai.

Pada prinsipnya, semakin besar sampel, maka akan semakin baik dan tingkat kesalahan dalam pengambilan kesimpulan akan semakin kecil. Namun, Roscoe (dalam Sugiyono, 2007) memberikan saran mengenai jumlah sampel untuk penelitian sebagai berikut:

a. Ukuran sampel yang layak dalam penelitian adalah antara 30 sampai 500.

b. Bila sampel dibagi dalam beberapa kategori, maka jumlah sampel untuk setiap kategori adalah minimal 30.

c. Bila penelitian menggunakan analisis multivariat (lebih dari 2 variabel; independent dan dependent variabel), maka jumlah anggota sampel adalah minimal 10 kali jumlah variabel yang diteliti.

d. Untuk penelitian sederhana, yang menggunakan kelompok kontrol dan kelompok eksperimen, maka jumlah sampel untuk setiap kelompok adalah antara 10-20 orang.

\section{Penelitian Kuantitaif}

Penelitian kuantitatif, menurut Robert Donmoyer (dalam Given, 2008: 713), adalah pendekatan- pendekatan terhadap kajian empiris untuk mengumpulkan, menganalisa, dan menampilkan data dalam bentuk numerik daripada naratif. Menurut Cooper \& Schindler (2006: 229), Penelitian kuantitatif mencoba melakukan pengukuran yang akurat terhadap sesuatu. Penelitian kuantitatif sering dipandang sebagai antitesis atau lawan dari penelitian kualitatif. Kasiram (2008: 149) dalam bukunya Metodologi Penelitian Kualitatif dan Kuantitatif, mendifinisikan penelitian kuantitatif adalah suatu proses menemukan pengetahuan yang menggunakan data berupa angka sebagai alat menganalisis keterangan mengenai apa yang ingin diketahui.

Penelitian kuantitatif didasarkan pada asumsi sebagai berikut (Nana Sudjana dan Ibrahim, 2001; Del Siegle, 2005, dan Johnson, 2005).

a. Bahwa realitas yang menjadi sasaran penelitian berdimensi tunggal, fragmental, dan cenderung bersifat tetap sehingga dapat diprediksi.

b. Variabel dapat diidentifikasi dan diukur dengan alat-alat yang objektif dan baku.

Karakteristik penelitian kuantitatif adalah sebagai berikut (Nana Sudjana dan Ibrahim, 2001 6-7; Suharsimi Arikunto, 2002 : 11; Johnson, 2005; dan Kasiram 2008: 149-150) :

a. Menggunakan pola berpikir deduktif (rasional-empiris atau topdown), yang berusaha memahami suatu fenomena dengan cara menggunakan konsep-konsep yang umum untuk menjelaskan fenomena-fenomena yang bersifat khusus. 
b. Logika yang dipakai adalah logika positivistik dan menghundari halhal yang bersifat subjektif.

c. Proses penelitian mengikuti prosedur yang telah direncanakan.

d. Tujuan dari penelitian kuantitatif adalah untuk menyususun ilmu nomotetik yaitu ilmu yang berupaya membuat hokum-hukum dari generalisasinya.

e. Subjek yang diteliti, data yang dikumpulkan, dan sumber data yang dibutuhkan, serta alat pengumpul data yang dipakai sesuai dengan apa yang telah direncanakan sebelumnya.

f. Pengumpulan data dilakukan melalui pengukuran dengan menggunakan alat yang objektif dan baku.

g. Peneliti menempatkan diri secara terpisah dengan objek penelitian, dalam arti dirinya tidak terlibat secara emosional dengan subjek penelitian.

h. Analisis data dilakukan setelah semua data terkumpul.

i. Hasil penelitian berupa generalisasi dan prediksi, lepas dari konteks waktu dan situasi.

Penelitian kuantitatif pelaksanaannya berdasarkan prosedur yang telah direncanakan sebelumnya. Adapun prosedur penelitian kuantitatif terdiri dari tahapan-tahapan kegiatan sebagai berikut.

a. Identifikasi permasalahan

b. Studi literatur.

c. Pengembangan kerangka konsep

d. Identifikasi dan definisi variabel, hipotesis, dan pertanyaan penelitian. e. Pengembangan disain penelitian.

f. Teknik sampling.

g. Pengumpulan dan kuantifikasi data.

h. Analisis data.

i. Interpretasi dan komunikasi hasil penelitian.

Dalam melakukan penelitian, peneliti dapat menggunakan metoda dan rancangan (design) tertentu dengan mempertimbangkan tujuan penelitian dan sifat masalah yang dihadapi. Berdasarkan sifat-sifat permasalahannya, penelitian kuantitatif dapat dibedakan menjadi beberapa tipe sebagai berikut (Suryabrata, 2000 : 15 dan Sudarwan Danim dan Darwis, 2003 : $69-78)$.
a. Penelitian deskriptif
b. Penelitian korelational
c. Penelitian kausal komparatif
d. Penelitian tindakan
e. Penelitian perkembangan
f. Penelitian eksperimen

Metode yang dipergunakan dalam penelitian kuantitatif, khusunya kuantitatif analitik adalah metode deduktif. Dalam metoda ini teori ilmiah yang telah diterima kebenarannya dijadikan acuan dalam mencari kebenaran selanjutnya. Jujun S. Suriasumantri dalam bukunya Ilmu dalam Perspektif Moral, Sosial, dan Politik (2000: 6) menyatakan bahwa pada dasarnya metoda ilmiah merupakan cara ilmu memperoleh dan menyusun tubuh pengetahuannya berdasarkan : a) kerangka pemikiran yang bersifat logis dengan argumentasi yang bersifat konsisten dengan pengetahuan sebelumnya yang telah berhasil disusun; b) menjabarkan hipotesis yang merupakan deduksi dari 
kerangka pemikiran tersebut; dan c) melakukan verifikasi terhadap hipotesis termaksud untuk menguji kebenaran pernyataannya secara faktual. Selanjutnya Jujun menyatakan bahwa kerangka berpikir ilmiah yang berintikan proses logico-hypotheticoverifikatif ini pada dasarnya terdiri dari langkah-langkah sebagai berikut (Suriasumantri, 2005 : 127-128).

a. Perumusan masalah, yang merupakan pertanyaan mengenai objek empiris yang jelas bata batasnya serta dapat diidentifikasikan faktorfaktor yang terkait di dalamnya.

b. Penyusunan kerangka berpikir dalam penyusunan hipotesis yang merupakan argumentasi yang menjelaskan hubungan yang mungkin terdapat antara berbagai faktor yang saling mengait dan membentuk konstelasi permasalahan. Kerangka berpikir ini disusun secara rasional berdasarkan premis-premis ilmiah yang telah teruji kebenarannya dengan memperhatikan faktorfaktor empiris yang relevan dengan permasalahan.

c. Perumusan hipotesis yang merupakan jawaban sementara atau dugaan terhadap pertanyaan yang diajukan yang materinya merupakan kesimpulan dari dari kerangka berpikir yang dikembangkan.

d. Pengujian hipotesis yang merupakan pengumpulan faktafakta yang relevan dengan hipotesis, yang diajukan untuk memperlihatkan apakah terdapat fakta-fakta yang mendukung hipoteisis tersebut atau tidak.

e. Penarikan kesimpulan yang merupakan penilaian apakah hipotesis yang diajukan itu ditolak atau diterima

\section{Daftar Pustaka}

Cooper, Donald R. dan Pamela S. Schindler. 2006. Metode riset bisnis, vol. 1 , edisi 9

(Business research methods, 9th edition); Budijanto, Didik Djunaedi, Damos Sihombing, penerjemah. Jakarta: Media Global Edukasi.

Given, Lisa M. (editor). 2008. The Sage encyclopedia of qualitative research methods.

Thousand Oaks: Sage.

Johnson, R. Burke. (2005) "Educatioal Research : Quantitative and Qualitative"

Internet

www.south.edu/coe/bset/john son .

Riduwan. 2009. Pengantar Statistika Sosial. Bandung: Alfabeta.

sambasalim.com

Siregar, Syofian. 2015. Statistika Terapan untuk Perguruan Tinggi. Jakarta: Prenadamedia

Sudjana, Nana dan Ibrahim. (2001)

Penelitian dan Penilaian Pendidikan.

Bandung : Sinar Baru Algensindo.

Suharsimi Arikunto (2002) Prosedur Penelitian : Suatu Pendekatan Praktik.

Jakarta : Rineka Cipta.

Sugiyono. 2013. Statistika untuk Penelitian. Bandung: Alfabeta. 
Sukardi. (2004) Metodologi

Penelitian Pendidikan : Kompetensi dan

Praktiknya. Jakarta : Bumi

Aksara.

Sumadi Suryabrata (2000)

Metodologi Penelitian. Jakarta : PT

Raja Grafindo Persada.

Wikipedia. 2016. Statistics, diakses dari situs

http://en.wikipedia.org/wiki/Statistics

pada April 2016 